\title{
NORTHERN PARULAS WEST OF LAKE WINNIPEG
}

PETER TAYLOR, P.O. Box 597, Pinawa, Manitoba R0E 1LO

BOB SHETTLER, 65 Charles Glen Drive, Headingley, Manitoba R4H 1A9 COLIN BRADSHAW, 9 Tynemouth Place, North Shields, England NE30 4BJ

The Northern Parula (Parula americana) is an attractive warbler that reaches the northwestern limit of its known breeding range in extreme southeastern Manitoba. ${ }^{3}$ Its bestknown strongholds in the province are in or near Whiteshell and Nopiming Provincial Parks, within about $50 \mathrm{~km}$ of the Ontario border. The possibility that its range extends west of Lake Winnipeg was rumoured in the 1960s, and stimulated at least one field trip to Beaver Creek and Calder's Dock on the western shore of that lake, 15 June 1969. ${ }^{3}$ The almost annual occurrence of this species as a migrant (admittedly a rare one) in Winnipeg in recent years also suggests that such a westerly population may exist.

This note documents recent observations of Northern Parulas at Beaver Creek (approx. 51 $20^{\prime} \mathrm{N}, 97^{\circ} 00^{\prime}$ $W)$, finally confirming the 30 -year-old rumours! Additional records for $\mathrm{He}$ cla Island and Grindstone Provincial Recreational Area (PRA), a little farther south, demonstrate that a significant population of Parulas exists in this part of the province. These locations are shown, along with the previously published breeding range of the Northern Parula, in Figure 1.

The Beaver Creek discovery was made by Bradshaw, who spent much of the summer of 1989 at Hodgson, Manitoba. ${ }^{1} \mathrm{He}$ was unaware of the suspected presence of Northern Parulas in the area, when he found three singing males, seeing one of them well, at Beaver Creek on 2 July 1989. Taylor visited the area at 7 a.m. on 18 June 1991 and also found three singing males along a 2 $\mathrm{km}$ stretch of Provincial Road 234 at Beaver Creek. The habitat was similar to that in breeding localities east of Lake Winnipeg, although somewhat less densely wooded. ${ }^{3}$ The Parulas were found in mature spruce and mixed-wood stands, and the vital nesting material, Usnea lichen, was present in quantity. Taylor returned to the same locality at 6 a.m. on 1 July 1993; despite rain and strong winds, one Parula was singing at the same spot as one of the 1991 birds, near a transmitter tower. A further visit under better conditions on 27 June 1997 turned up two singing Parulas.

Shettler has observed Northern Parulas in Grindstone PRA each year since 1982. Parulas have been seen at many points along the road running from Highway 8 to the cottage development at Little Grindstone Point. The area around Little Grindstone Beach is very reliable for this species, with as many as four singing males observed on three different dates: 16 May 1987, 23 May 1989 and 3 June 1992. Males typically arrive on territory in mid-May, the earliest observation being on 14 May 1989. The latest sighting was on 22 August 1987. The Parulas observed in the Grindstone area tend to favour mixed-wood stands of trees 


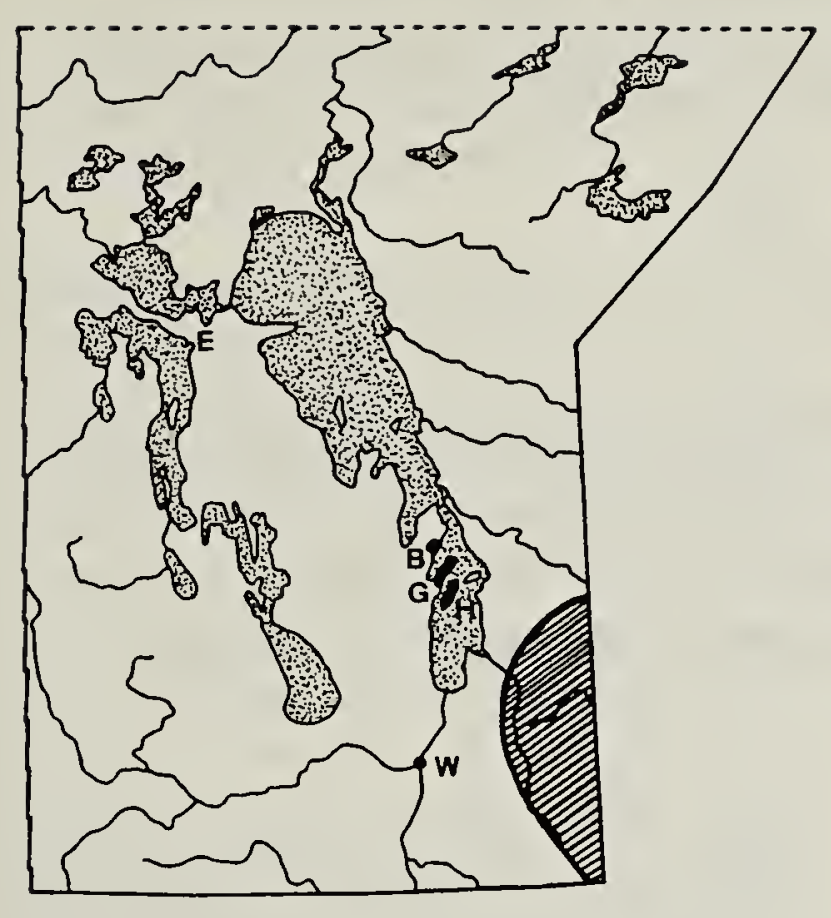

Figure 1. Southern Manitoba, showing the previously published range of the Northern Parula (shaded area, based on ref. 3). Labelled localities are: $B=$ Beaver Creek; $E=$ Easterville region; $G=$ Grindstone PRA; $H=$ Hecla Island; $W=$ Winnipeg.

that are dominated by mature $\mathrm{Bal}-$ sam Fir and White Birch.

Bradshaw also found Northern Parulas on Hecla Island during his 1989 and 1991 visits to Manitoba: two each on 20 August 1989 and 16 August 1991, and one each on 6 and 19 August 1989 and 29 August $1991 .^{1,2}$ These may have been either migrants or local breeders. Shettler has noted singing males on three oc- casions on a Breeding Bird Survey route on Hecla Island: one on 9 June 1989, two on 10 June 1994 and one on 16 June 1995. A little farther south, R.F. Koes and R.W. Knapton heard a singing male Northern Parula, evidently a migrant, in deciduous woods near Gimli on 15 May 1977.

These records demonstrate that the Northern Parula has established a small population on the western shore of Lake Winnipeg. This is a significant extension of the species' published range in Manitoba; it confirms earlier suspicions of such a population, rather than being a recent range expansion. Much of the region is inaccessible, so the extent of this population is hard to estimate; it is unlikely to be limited to the three localities described here. Taylor did not find this species during Breeding Bird Surveys in the Easterville area, about $300 \mathrm{~km}$ farther northwest, in 1991, 1993 and 1994, although there appeared to be appropriate habitat.

1. BRADSHAW, C. and C. BRADSHAW. 1989. Central Manitoba, 17th June1st Sept. 89. Unpublished manuscript.

2. BRADSHAW, C. and C. BRADSHAW. 1991. Bird migration through Hecla Island, Manitoba, August 91. Unpublished manuscript.

3. MCNICHOLL, M.K. and P. TAYLOR. 1982. The Northern Parula in Manitoba. Blue Jay 40:109-119. 